\title{
Litterfall and growth dynamics relationship with the meteorological variability in three forests in the Montseny natural park
}

\author{
Jordi Bou $\bowtie$, Antònia Caritat, Lluís Vilar \\ University of Girona - Institute of the Environment, Laboratory of Landscape Analysis and Management, \\ Campus Montilivi, 17071 Girona, Spain, phone: 9724182 79, fax: 97241 81 50, e-mail: jordi.bou.manobens@gmail.com
}

\begin{abstract}
We assessed the influence of some environmental conditions (temperature and rainfall) on the litterfall and BAI (basal area increment), in three close forests in the Montseny massif (NE part of the Iberian peninsula, Spain). Two of them are composed of deciduous species Fagus sylvatica and Quercus petraea, and the other one is a Mediterranean evergreen species, Quercus ilex. We have collected monthly data about litterfall and radial growth since 2007. For each forest there are tree plots, with litterfall traps and band dendrometers. This data has been related with the meteorological parameters of meteorological station closed to the study area. Our results show that F. sylvatica recorded the biggest drop in annual litterfall $\left(6 \mathrm{Mg} \cdot \mathrm{ha}^{-1} \cdot \mathrm{year}^{-1}\right)$, followed by Q. ilex $\left(4.34 \mathrm{Mg} \cdot \mathrm{ha}^{-1} \cdot \mathrm{year}^{-1}\right)$ and Quercus petraea $\left(4.4 \mathrm{Mg} \mathrm{ha}^{-1} \cdot \mathrm{year}^{-1}\right)$ and that all the values were similar to those observed in other forests and mountains with the same state of maturity. Regarding the litterfall, the investigation found a decline in the leaves fall in deciduous trees in years with hot summers. In addition, these warm summers produce a decline in the $F$. sylvatica BAI, but not in $Q$. petraea. Concerning growth, we found that $Q$. petraea increases the BAI on the study period while $F$. sylvatica does not. In conclusion, we believe that in the future $Q$. petraea will be more tolerant to the warm conditions than F. sylvatica, making the former a possible replacement of the second species.
\end{abstract}

\section{KeY WORDS}

litterfall, BAI, forest ecology, Quercus petraea, Quercus ilex, Fagus sylvatica, Montseny

\section{INTRODUCTION}

The forests in the Iberian peninsula are susceptible to the effects of climate change and some have already been affected by recent summer droughts (Jump et al. 2006; Vayreda et al. 2013b). However, not all the forests suffer at the same level, deciduous forests are going to suffer a lot of negative effects because of drought and evergreen forests will not suffer so much (Aranda et al. 2000; Fotelli et al. 2009; Vayreda et al. 2013a). One of the effects of climate change could prompt species to move to higher altitudes (Peñuelas and Boada 2003) or provoke the replacement of deciduous species by evergreen Mediterranean species - above all, Quercus ilex - which is more resistant to prolonged dry summers (Vayreda et al. 2013a). 
Climatic conditions like precipitation and temperature changes have influence in key processes of forest like litterfall and radial growth (Bugmann 1997; Jacoby and D'Arrigo 1997; Liu et al. 2004; Weber et al. 2008; Andivia et al. 2013). The study of litterfall and growth is very important to evaluate the impact of climatic change. An example of this is the study of Jump et al. 2006, which found how warming and drought conditions have a negative effect on Fagus sylvatica growth.

In order to know some effects of meteorological variations on the forests of Montseny (NE Spain), we analyse the relationship between the BAI (basal area increment) and litterfall production with the meteorological data in three type of forest. The Montseny massif is a quite interesting place to make this study because some forests are located on the edge of their distribution, where the effects of climate change will appear first (Mátyás 2010). In addition, in the Montseny area we can find forests with different vulnerabilities (especially climate change) very close to each other, in the same altitude, substrate, precipitation, temperature, etc. The most vulnerable are $F$. sylvatica forest and Quercus petraea forest whereas the least vulnerable is $Q$. ilex forest (Vayreda et al. 2013a), because this evergreen tree has mechanisms that allow itself to adapt to the increased water stress typical of the Mediterranean region.

\section{MAterial AND METHODS}

\section{Area of study}

The study area is located in the Montseny, a massif of the Catalan pre-littoral mountain range (NE of the Iberian peninsula, Spain), with an altitude ranging from 100 to $1700 \mathrm{~m}$. Therefore, the Montseny has a very marked gradient of climate and vegetation, from the Mediterranean climate with summer drought in the low Montseny to the humid climate in the high Montseny, and even cold at the top of the mountain. For this reason, the massif has great landscape diversity, with deciduous and evergreen forests. At a lithological level, the Montseny massif is mainly silicic, with granitic or Palaeozoic substrate (Bolòs 1983), and specifically the study area is located upon the large granodioritic batholith of Montseny-Guilleries. The climate of the studied area has a poorly marked summer drought, and also regular and abundant rainfall (Figure 1).

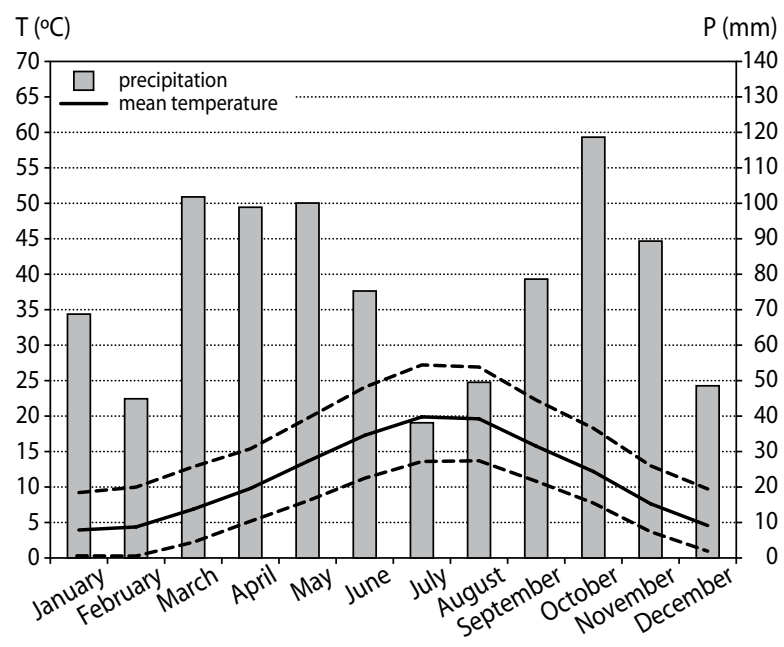

Figure 1. Climate diagram of Viladrau during the study period 2006-2012

\section{Experimental plots}

For the study we have selected an old $F$. sylvatica forest in Coll de Te, not exploited in the last 50 years, and two forests in Marmolers, one of Q. petraea and the other of $Q$. ilex. The $Q$. petraea forest is a quite young forest that has not been managed for the last 30 years. The $Q$. ilex forest underwent a selective logging of the biggest trees in 2008 to reduce its density. As we can see at Table 1, the Marmolers forest was at $850 \mathrm{~m}$, with a slope of $20 \%$.

Table 1. Characteristics of the three studied forests

\begin{tabular}{|c|c|c|c|}
\hline & $\begin{array}{c}\text { Fagus } \\
\text { sylvatica }\end{array}$ & $\begin{array}{l}\text { Quercus } \\
\text { petraea }\end{array}$ & $\begin{array}{l}\text { Quercus } \\
\text { ilex }\end{array}$ \\
\hline UTM & $\begin{array}{l}456102 X \\
4626901 Y\end{array}$ & $\begin{array}{l}457180 \mathrm{X} \\
4627004 \mathrm{Y}\end{array}$ & $\begin{array}{l}457206 \mathrm{X} \\
4627098 \mathrm{Y}\end{array}$ \\
\hline $\begin{array}{l}\text { Altitude } \\
\text { (ma.m.s.1.) }\end{array}$ & 1000 & 850 & 850 \\
\hline Orientation & East & South-east & South-east \\
\hline Slope & $23-29 \%$ & $18-21 \%$ & $24-28 \%$ \\
\hline Substratum & Granodiorite & Granodiorite & Granodiorite \\
\hline Soil depth & $>40 \mathrm{~cm}$ & $24-32 \mathrm{~cm}$ & $22-30 \mathrm{~cm}$ \\
\hline \multirow{2}{*}{ Tree level } & \multirow{2}{*}{$\begin{array}{c}\text { F. sylvatica } \\
100 \%\end{array}$} & $\begin{array}{c}\text { Q. petraea } \\
93 \%\end{array}$ & $\begin{array}{l}\text { Q.ilex } \\
75 \%\end{array}$ \\
\hline & & $\begin{array}{l}\text { Castanea } \\
\text { sativa } 7 \%\end{array}$ & $\begin{array}{c}Q . \text { petraea } \\
25 \%\end{array}$ \\
\hline Density $\mathrm{n} / \mathrm{ha}$ & $408 \pm 38$ & $2601 \pm 322$ & $732 \pm 32$ \\
\hline Biomass $\mathrm{Mg} / \mathrm{ha}$ & $237 \pm 38$ & $217 \pm 9$ & $76 \pm 25$ \\
\hline
\end{tabular}


The Coll de Te forest is in a very similar place, a little higher at $1000 \mathrm{~m}$. As the forests are very close, for both zones we use the same meteorological data from the nearest station, in Viladrau (451837X, 4632388Y). The data obtained are monthly, but for the study we use seasonal and annual data depending of the analysis.

In 2006 three experimental $F$. sylvatica plots of $400 \mathrm{~m}^{2}$ were defined at Coll de Te, while in the $Q$. petraea and $Q$. ilex forest at Marmolers we defined three circular plots with a radius of $10 \mathrm{~m}$, for each forest type (both at square UTM: 31T DG52). We also typify the three forests, but we repeated that process in $Q$. ilex forest after the logging (Table 1).

\section{Litterfall sampling}

In summer 2006, five litter traps covering an area of $0.25 \mathrm{~m}^{2} /$ trap were installed randomly in each plot of Coll de Te and Marmolers, like in other studies of litterfall (Oliva et al. 1992; Caritat et al. 2006). The samples were collected monthly, and taken to a laboratory, where they were dried at $75^{\circ} \mathrm{C}$ for 24 hours. When the samples were dry they were classified according to four fractions: leaves, twigs, acorns and others.

\section{Growth measurements}

To study tree growth, in 2007 we placed band dendrometers (Infoagro DB-20, precision 0,1 $\mathrm{mm}$ ) to monitor the monthly trees' radial growth (Figure 2), because they measure linear displacement of a sensing band pressed against the bark of the stem. We installed five dendrometers randomly at the breast height in trees over $10 \mathrm{~cm}$ of diameter, in each plot of the three studied zones.

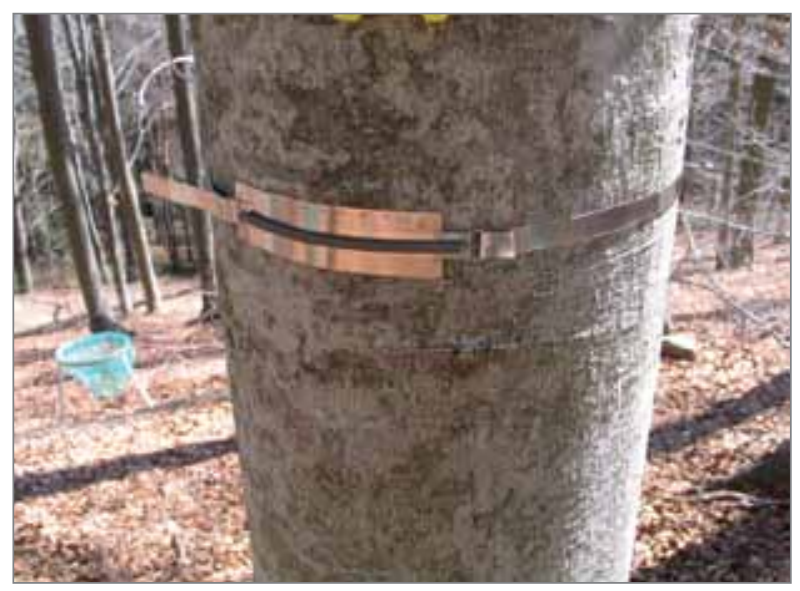

Figure 2. Beech tree at Coll de Te with dendrometers
During autumn 2008 the Marmolers Q. ilex forest was cleared for firewood, which meant that all the traps and dendrometers had to be removed. They were subsequently re-installed to conduct a new inventory of the tree layer, and we find an increment in the radial growth as a consequence of the density reduction.

\section{Data analysis}

We use R software to study the relationship of growth and litterfall with meteorological variables. Before any analysis we tested the normality of the litterfall and the growth with Shapiro-Wilk test, and we transformed the data that does not have a normal distribution with a logarithmic equation $(\mathrm{y}=\log 10[\mathrm{x}+1])$.

The effect of meteorological variables (seasonal and annual data) on the production of litterfall was studied seasonally, using seasons such as winter (I, II, III), spring (IV, V, VI), summer (VII, VIII, IX) and autumn (X, XI, $\mathrm{XII})$. This seasonal litterfall was modelled as a simple linear regression to analyse what kind of relation they have.

In order to analyze radial growth, the data was transformed to increase in basal area (BAI). This conversion it's to avoid the growth dependence of the tree age, because BAI mathematically is less biased by stem geometry (Weber et al. 2008). To calculate the BAI first we calculated the mean BA (basal area) among the trees of each plot for each year. Finally the annual BAI has been calculated as the difference between the BA of a year and the previous year $\left(\mathrm{BAI}=\sum \mathrm{BA}_{\mathrm{i}}-\mathrm{BA}_{\mathrm{i}-1}\right)$. This annual BAI was analysed as a simple linear regression to find what kind of relation they have, with the seasonal and annual climate data.

\section{Results}

\section{Litterfall}

The largest annual production of litterfall is the one of $F$. sylvatica $\left(6.00 \pm 0.86 \mathrm{Mg} \cdot \mathrm{ha}^{-1} \cdot \mathrm{year}^{-1}\right)$, followed by $Q$. petraea $\left(4.44 \pm 0.91 \mathrm{Mg} \cdot \mathrm{ha}^{-1} \cdot \mathrm{year}^{-1}\right)$ and $Q$. ilex $\left(4.34 \pm 0.17 \mathrm{Mg}^{-h^{-1}}\right.$ year $\left.^{-1}\right)$. Q. ilex leaves represented $55.7 \%$ of the total litterfall, while in the deciduous species the leaf litterfall fraction had values of $71.32 \%$ in Q. petraea and $69.64 \%$ in F. sylvatica. The observed percentage for fruit in the litterfall in the $Q$. petraea woods was $5.78 \%, 12.55 \%$ in the $F$. sylvatica and $15.89 \%$ in $Q$. ilex forest. 
Figure 3 shows the monthly variations in litterfall for the deciduous species. The main peaks are due to leaf fall and usually occur in October or November. Since 2009 maximum leaf fall in $F$. sylvatica has occurred just before the leaf fall in $Q$. petraea. There were two other remarkable peaks, one in September 2008 and the other one in May 2009.

In $Q$. ilex forest, however, there are two main peaks in the intra-year litterfall curve (Figure 4). The first peak takes place in spring, in May-June, and the second one usually in November. The second peak in the intra-year litterfall occurs in large part due to leaf fall in Q. petraea trees present in the plot.

Litterfall shows seasonal regressions with various meteorological variables. On the one hand, there are direct relationships, but there are cases in which the effect is delayed by the weather conditions which precede that particular season (Table 2, 3, 4 and 5).

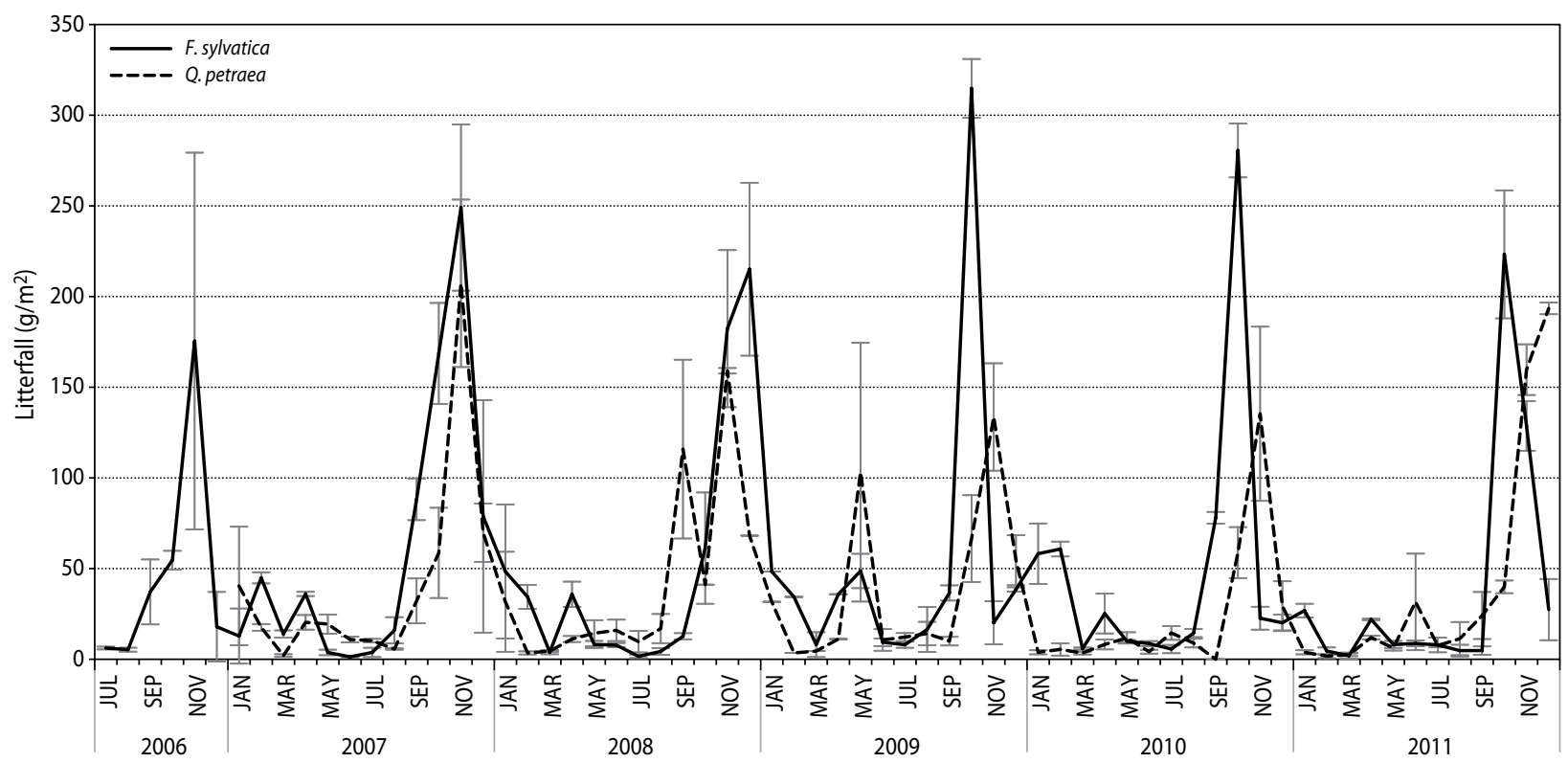

Figure 3. Monthly litterfall registered in deciduous species

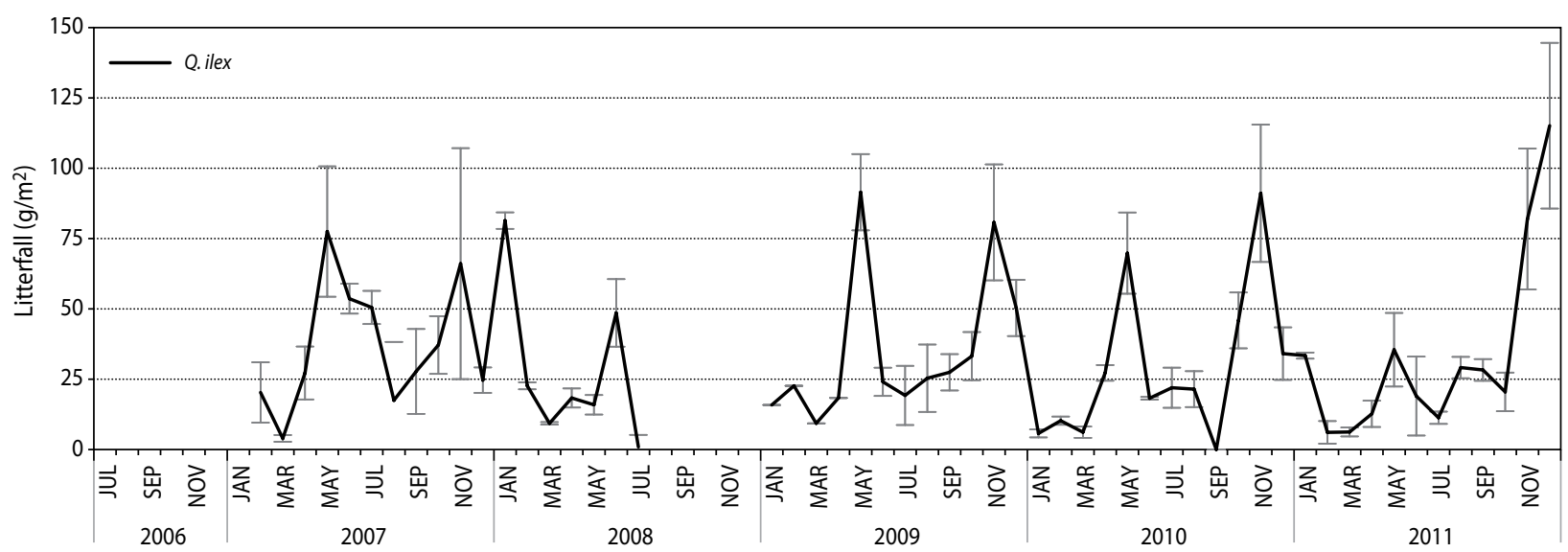

Figure 4. Monthly total litterfall recorded in the holm oak forest at Marmolers. The bars correspond to the standard deviation (SD). There were no data for the second half of 2008 
Table 2. Linear regression between the meteorological data and the Leaves of the same season for the three studied species (Quercus ilex, Quercus petraea and Fagus sylvatica). The first P-value tests the regression model, the second P-value corresponds to the t-test of the intercept (a) whereas the third P-value corresponds to the t-test of whether the regression coefficient or slope (b) is significantly different from 1. Also there are the coefficient of determination $\left(\mathrm{r}^{2}\right)$ and the residual standard error (SE) of the regression model. The table only contents the season that have some kind of significant linear regression. The meteorological data used are: precipitation (P), temperature (T) and wind (W)

\begin{tabular}{|c|c|c|c|c|c|c|c|c|c|c|}
\hline Species & $\begin{array}{c}\text { Litterfall } \\
\text { season }\end{array}$ & $\begin{array}{l}\text { Meteorological } \\
\text { variable }\end{array}$ & $\begin{array}{l}\text { Meteorological } \\
\text { variable season }\end{array}$ & $\mathrm{r}^{2}$ & $\mathrm{p}$ & SE & $\mathrm{a}$ & $\mathrm{p}$ & $\mathrm{b}$ & $\mathrm{p}$ \\
\hline \multirow{8}{*}{$\begin{array}{l}\text { Fagus } \\
\text { sylvatica }\end{array}$} & \multirow{3}{*}{ Winter } & $\mathrm{T}$ & Autumn & 0,291 & $<0,0500$ & 17,600 & $-30,157$ & 0,341 & 8,767 & $<0,0500$ \\
\hline & & $\mathrm{T}$ & Winter & 0,462 & $<0,0100$ & 15,350 & 111,571 & $<0,001$ & $-13,887$ & $<0,0100$ \\
\hline & & W & Winter & 0,877 & $<0,0001$ & 7,328 & $-55,522$ & $<0,0001$ & 94,974 & $<0,0001$ \\
\hline & Spring & W & Spring & 0,718 & $<0,0001$ & 4,064 & 35,288 & $<0,0001$ & $-39,173$ & $<0,0001$ \\
\hline & Summer & $\mathrm{W}$ & Summer & 0,439 & $<0,0100$ & 12,260 & $-118,720$ & $<0,0500$ & 324,960 & $<0,0100$ \\
\hline & \multirow{3}{*}{ Autumn } & $\mathrm{T}$ & Autumn & 0,228 & $<0,0500$ & 68,580 & 564,950 & $<0,0010$ & $-30,340$ & $<0,0500$ \\
\hline & & $\mathrm{P}$ & Spring & 0,257 & $<0,0500$ & 67,310 & 239,631 & $<0,0001$ & 0,284 & $<0,0500$ \\
\hline & & $\mathrm{T}$ & Summer & 0,281 & $<0,0500$ & 66,200 & 1806,910 & $<0,0100$ & $-81,140$ & $<0,0500$ \\
\hline \multirow{9}{*}{$\begin{array}{l}\text { Quercus } \\
\text { ilex }\end{array}$} & \multirow{2}{*}{ Winter } & $\mathrm{P}$ & Autumn & 0,340 & $<0,0500$ & 4,561 & 22,883 & $<0,0001$ & $-0,026$ & $<0,0500$ \\
\hline & & $\mathrm{T}$ & Winter & 0,405 & $<0,0500$ & 4,329 & $-1,373$ & 0,8510 & 3,705 & $<0,0500$ \\
\hline & Spring & $\mathrm{T}$ & Autumn & 0,414 & $<0,0100$ & 20,760 & $-38,734$ & 0,30000 & 13,554 & $<0,0100$ \\
\hline & \multirow{4}{*}{ Summer } & $\mathrm{T}$ & Spring & 0,455 & $<0,0500$ & 10,240 & $-110,269$ & 0,056 & 10,784 & $<0,0500$ \\
\hline & & $\mathrm{P}$ & Summer & 0,514 & $<0,0100$ & 9,671 & 95,085 & $<0,0010$ & $-0,418$ & $<0,0100$ \\
\hline & & $\mathrm{T}$ & Summer & 0,451 & $<0,0500$ & 10,280 & 352,287 & $<0,0100$ & $-17,227$ & $<0,0500$ \\
\hline & & $\mathrm{T}$ & Winter & 0,797 & $<0,0001$ & 6,249 & $-20,921$ & $<0,0100$ & 11,515 & $<0,0001$ \\
\hline & \multirow{2}{*}{ Autumn } & $\mathrm{P}$ & Autumn & 0,339 & $<0,0500$ & 40,110 & 84,229 & $<0,0100$ & 0,183 & $<0,0500$ \\
\hline & & $\mathrm{W}$ & Summer & 0,388 & $<0,0500$ & 38,590 & 566,500 & $<0,0010$ & $-971,200$ & $<0,0500$ \\
\hline \multirow{6}{*}{$\begin{array}{l}\text { Quercus } \\
\text { petraea }\end{array}$} & \multirow{2}{*}{ Winter } & W & Autumn & 0,333 & $<0,0500$ & 9,261 & 32,776 & $<0,0010$ & $-14,913$ & $<0,0500$ \\
\hline & & $\mathrm{P}$ & Winter & 0,632 & $<0,0010$ & 6,596 & 32,987 & $<0,0001$ & $-0,074$ & $<0,0010$ \\
\hline & \multirow{2}{*}{ Spring } & $\mathrm{P}$ & Spring & 0,323 & $<0,0500$ & 0,279 & 1,908 & $<0,0001$ & $-0,002$ & $<0,0500$ \\
\hline & & $\mathrm{T}$ & Spring & 0,316 & $<0,0500$ & 0,280 & $-1,535$ & 0,1950 & 0,205 & $<0,0500$ \\
\hline & \multirow{2}{*}{ Autumn } & $\mathrm{W}$ & Autumn & 0,496 & $<0,0100$ & 57,620 & 376,800 & $<0,0001$ & $-124,190$ & $<0,0100$ \\
\hline & & $\mathrm{P}$ & Summer & 0,400 & $<0,0500$ & 62,850 & 579,177 & $<0,0010$ & $-2,421$ & $<0,0500$ \\
\hline
\end{tabular}

Regarding the fall of leaves (Table 2) in $Q$. ilex, it is mainly linked to temperature. During mild winters less leaves fall, although there is a negative relationship with precipitation during the previous autumn. Regarding spring, we do not see the direct effect of any variable of the season, but we see a significant relationship between spring, with a lot of falling leaves, and warmer autumns. In summer $Q$. ilex shows that a high temperature is associated with a decrease in leaf fall and in the same direction with summer precipitation, but much milder. At the same time increase in the temperature in spring and winter generated an increase in leaf fall during summer. Finally, autumn is the only season with a direct positive relationship between autumn precipitation and falling leaves during this period. However, this link is not as important as the one observed between summer wind and foliage fall during this last season.

Regarding acorn (Table 3), there is a peak fall in autumn that can increase if it is a rainy autumn. However, this value can decrease if the summer is windy. Falling acorns in winter are related to the wind of the previous season, which reduces the fall in winter. In a cold autumn the fall moves to winter, but when the winter is warm falling acorn increases. 
Table 3. Linear regression between the meteorological data and the Acorn of the same season for the three studied species (Quercus ilex, Quercus petraea and Fagus sylvatica). The first P-value tests the regression model, the second P-value corresponds to the t-test of the intercept (a) whereas the third P-value corresponds to the t-test of whether the regression coefficient or slope (b) is significantly different from 1 . Also there are the coefficient of determination $\left(\mathrm{r}^{2}\right)$ and the residual standard error (SE) of the regression model. The table only contents the season that have some kind of significant linear regression. The meteorological data used are: precipitation $(\mathrm{P})$, temperature $(\mathrm{T})$ and wind $(\mathrm{W})$

\begin{tabular}{|c|c|c|c|c|c|c|c|c|c|c|}
\hline Species & $\begin{array}{c}\text { Litterfall } \\
\text { season }\end{array}$ & $\begin{array}{l}\text { Meteorological } \\
\text { variable }\end{array}$ & $\begin{array}{l}\text { Meteorological } \\
\text { variable season }\end{array}$ & $r^{2}$ & $\mathrm{p}$ & SE & $\mathrm{a}$ & $\mathrm{p}$ & $\mathrm{b}$ & $\mathrm{p}$ \\
\hline \multirow{3}{*}{$\begin{array}{l}\text { Fagus } \\
\text { sylvatica }\end{array}$} & Winter & $\mathrm{T}$ & Winter & 0,551 & $<0,0100$ & 0,284 & 2,512 & $<0,0001$ & $-0,307$ & $<0,0100$ \\
\hline & Spring & $\mathrm{T}$ & Spring & 0,353 & $<0,0500$ & 0,302 & 3,899 & $<0,0100$ & $-0,240$ & $<0,0500$ \\
\hline & Autumn & $\mathrm{T}$ & Autumn & 0,257 & $<0,0500$ & 23,210 & 116,197 & $<0,0100$ & $-11,094$ & $<0,0500$ \\
\hline \multirow{6}{*}{$\begin{array}{l}\text { Quercus } \\
\text { ilex }\end{array}$} & \multirow{4}{*}{ Winter } & $\mathrm{T}$ & Autumn & 0,581 & $<0,0100$ & 0,404 & 4,736 & $<0,0100$ & $-0,513$ & $<0,0100$ \\
\hline & & $\mathrm{W}$ & Autumn & 0,835 & $<0,0001$ & 0,253 & 2,197 & $<0,0001$ & $-1,153$ & $<0,0001$ \\
\hline & & $\mathrm{T}$ & Winter & 0,605 & $<0,0100$ & 0,392 & $-1,575$ & $<0,0500$ & 0,502 & $<0,0100$ \\
\hline & & $\mathrm{W}$ & Winter & 0,442 & $<0,0500$ & 0,465 & 2,663 & $<0,0100$ & $-1,793$ & $<0,0500$ \\
\hline & \multirow{2}{*}{ Autumn } & $\mathrm{P}$ & Autumn & 0,379 & $<0,0500$ & 8,183 & 20,727 & $<0,0100$ & 0,041 & $<0,0500$ \\
\hline & & $\mathrm{W}$ & Summer & 0,383 & $<0,0500$ & 8,162 & 122,220 & $<0,0010$ & $-203,120$ & $<0,0500$ \\
\hline \multirow{5}{*}{$\begin{array}{l}\text { Quercus } \\
\text { petraea }\end{array}$} & \multirow{2}{*}{ Spring } & $\mathrm{P}$ & Spring & 0,348 & $<0,0500$ & 0,400 & 1,414 & $<0,0100$ & $-0,003$ & $<0,0500$ \\
\hline & & $\mathrm{T}$ & Spring & 0,287 & $<0,0500$ & 0,418 & $-3,468$ & 0,0590 & 0,286 & $<0,0500$ \\
\hline & \multirow{2}{*}{ Summer } & $\mathrm{P}$ & Spring & 0,040 & $<0,0500$ & 0,428 & $-0,280$ & 0,5390 & 0,004 & $<0,0500$ \\
\hline & & $\mathrm{T}$ & Spring & 0,421 & $<0,0100$ & 0,420 & 6,156 & $<0,0100$ & $-0,387$ & $<0,0100$ \\
\hline & Autumn & $\mathrm{W}$ & Autumn & 0,731 & $<0,0001$ & 0,192 & $-0,091$ & 0,4170 & 0,002 & $<0,0001$ \\
\hline
\end{tabular}

Twigs fall is explained by several factors (Table 4), especially wind. Winter and spring do not have a very clear pattern, while during summer there seems to be a clear relationship between wind and falling twigs. However, summer wind has implications in the autumn twigs fall, because the windier it is in summer, the less twigs fall in autumn, at the maximum drop. Finally, for other fractions the only clear relationship is that the summer fall of this fraction depends on summer temperatures and spring wind.

Table 4. Linear regression between the meteorological data and the litterfall (Others and Twigs) of the same season for the three studied species (Quercus ilex, Quercus petraea and Fagus sylvatica). The first P-value tests the regression model, the second P-value corresponds to the t-test of the intercept (a) whereas the third P-value corresponds to the t-test of whether the regression coefficient or slope (b) is significantly different from 1 . Also there are the coefficient of determination $\left(\mathrm{r}^{2}\right)$ and the residual standard error (SE) of the regression model. The table only contents the season that have some kind of significant linear regression. The meteorological data used are: precipitation $(\mathrm{P})$, temperature $(\mathrm{T})$ and wind $(\mathrm{W})$

\begin{tabular}{|c|c|c|c|c|c|c|c|c|c|c|c|}
\hline Species & Litterfall & $\begin{array}{l}\text { Litterfall } \\
\text { season }\end{array}$ & $\begin{array}{c}\text { Meteorological } \\
\text { variable }\end{array}$ & $\begin{array}{l}\text { Meteorological } \\
\text { variable season }\end{array}$ & $\mathrm{r}^{2}$ & $\mathrm{p}$ & SE & $\mathrm{a}$ & $\mathrm{p}$ & $\mathrm{b}$ & $\mathrm{p}$ \\
\hline \multirow{2}{*}{$\begin{array}{l}\text { Quercus } \\
\text { ilex }\end{array}$} & \multirow{2}{*}{ Twigs } & Summer & $\mathrm{W}$ & Summer & 0,425 & $<0,05$ & 0,188 & $-1,467$ & 0,115 & 5,122 & $<0,05$ \\
\hline & & Autumn & $\mathrm{W}$ & Summer & 0,538 & $<0,01$ & 9,850 & 175,850 & $<0,010$ & 336,250 & $<0,01$ \\
\hline \multirow{2}{*}{$\begin{array}{l}\text { Quercus } \\
\text { ilex }\end{array}$} & \multirow{3}{*}{ Others } & \multirow{3}{*}{ Summer } & $\mathrm{T}$ & Summer & 0,505 & $<0,01$ & 3,402 & 62,464 & $<0,010$ & $-3,958$ & $<0,01$ \\
\hline & & & $\mathrm{W}$ & Spring & 0,476 & $<0,05$ & 3,500 & 18,554 & $<0,001$ & $-18,846$ & $<0,05$ \\
\hline $\begin{array}{l}\text { Quercus } \\
\text { petraea }\end{array}$ & & & W & Summer & 0,460 & $<0,01$ & 0,163 & $-1,574$ & $<0,050$ & 5,243 & $<0,01$ \\
\hline
\end{tabular}

In relation to the total litterfall (Table 5), we can see that the direct relationship with autumn and winter me- teorological dates is similar to that of acorn and leaves. With regard to indirect factors, we also found similar 
relationships with acorn, as wind and autumn temperature have implications for winter litterfall. In the case of summer wind we can see that it reduces the litterfall in autumn.

We can see the relationship between litterfall of Q. petraea and meteorological variables season in Table 2. Falling autumn leaves of $Q$. petraea have a negative regression with the wind. In addition, we notice a negative regression between autumn wind and the fall that oc- curs during winter. With regard to precipitation, the more humid a summer is, more leaves fall during autumn and vice versa. However, there is a negative regression between spring and summer temperature and autumn fall. In summer no significant relationship is found between temperature and falling leaves, but it occurs in spring, when there is a positive regression. Finally, leaves fall is low in autumn if more wind has been registered before summer, since they have fallen during summer.

Table 5. Linear regression between the meteorological data and the Total of the same season for the three studied species (Quercus ilex, Quercus petraea and Fagus sylvatica). The first P-value tests the regression model, the second P-value corresponds to the t-test of the intercept (a) whereas the third P-value corresponds to the t-test of whether the regression coefficient or slope (b) is significantly different from 1 . Also there are the coefficient of determination $\left(\mathrm{r}^{2}\right)$ and the residual standard error $(\mathrm{SE})$ of the regression model. The table only contents the season that have some kind of significant linear regression. The meteorological data used are: precipitation $(\mathrm{P})$, temperature $(\mathrm{T})$ and wind $(\mathrm{W})$

\begin{tabular}{|c|c|c|c|c|c|c|c|c|c|c|}
\hline Species & $\begin{array}{c}\text { Litterfall } \\
\text { season }\end{array}$ & $\begin{array}{l}\text { Meteorological } \\
\text { variable }\end{array}$ & $\begin{array}{l}\text { Meteorological } \\
\text { variable season }\end{array}$ & $r^{2}$ & $\mathrm{p}$ & SE & $\mathrm{a}$ & $\mathrm{p}$ & $\mathrm{b}$ & $\mathrm{p}$ \\
\hline \multirow{4}{*}{$\begin{array}{l}\text { Fagus } \\
\text { sylvatica }\end{array}$} & \multirow{2}{*}{ Winter } & $\mathrm{T}$ & Winter & 0,347 & $<0,0500$ & 29,220 & 189,471 & $<0,0010$ & $-20,797$ & $<0,0500$ \\
\hline & & $\mathrm{W}$ & Winter & 0,546 & $<0,0100$ & 24,360 & $-48,030$ & 0,1730 & 129,500 & $<0,0100$ \\
\hline & Summer & $\mathrm{W}$ & Summer & 0,244 & $<0,0500$ & 33,740 & $-197,200$ & 0,0990 & 575,700 & $<0,0500$ \\
\hline & Autumn & $\mathrm{T}$ & Autumn & 0,289 & $<0,0500$ & 92,830 & 768,090 & $<0,0500$ & $-48,140$ & $<0,0500$ \\
\hline \multirow{6}{*}{$\begin{array}{l}\text { Quercus } \\
\text { ilex }\end{array}$} & \multirow{4}{*}{ Winter } & $\mathrm{T}$ & Autumn & 0,535 & $<0,0100$ & 0,186 & 3,308 & $<0,0001$ & $-0,215$ & $<0,0100$ \\
\hline & & $\mathrm{W}$ & Autumn & 0,813 & $<0,0001$ & 0,118 & 2,258 & $<0,0001$ & $-0,497$ & $<0,0001$ \\
\hline & & $\mathrm{T}$ & Winter & 0,804 & $<0,0001$ & 0,121 & 0,453 & $<0,0500$ & 0,253 & $<0,0001$ \\
\hline & & $\mathrm{W}$ & Winter & 0,483 & $<0,0500$ & 0,196 & 2,503 & $<0,0001$ & $-0,817$ & $<0,0500$ \\
\hline & \multirow{2}{*}{ Autumn } & $\mathrm{P}$ & Autumn & 0,531 & $<0,0100$ & 48,750 & 118,623 & $<0,0100$ & 0,330 & $<0,0100$ \\
\hline & & $\mathrm{W}$ & Summer & 0,584 & $<0,0100$ & 45,900 & 974,600 & $<0,0010$ & $-1720,300$ & $<0,0100$ \\
\hline \multirow{4}{*}{$\begin{array}{l}\text { Quercus } \\
\text { petraea }\end{array}$} & Winter & $\mathrm{P}$ & Winter & 0,569 & $<0,0100$ & 16,650 & 66,292 & $<0,0001$ & $-0,154$ & $<0,0100$ \\
\hline & \multirow{2}{*}{ Spring } & $\mathrm{P}$ & Spring & 0,335 & $<0,0500$ & 0,219 & 2,249 & $<0,0010$ & $-0,002$ & $<0,0500$ \\
\hline & & $\mathrm{T}$ & Spring & 0,323 & $<0,0500$ & 0,221 & $-0,515$ & 0,5710 & 0,164 & $<0,0500$ \\
\hline & Autumn & W & Autumn & 0,383 & $<0,0500$ & 67,770 & 547,810 & $<0,0001$ & $-258,850$ & $<0,0500$ \\
\hline
\end{tabular}

Spring temperature has a positive regression with falling acorn in spring and a negative regression in summer (Table 3). However, spring precipitation has a negative regression with spring falling acorn and a positive regression with acorn fall in summer. We also observed a positive relationship between precipitation of autumn and acorns fall of this period. Others have a significant relationship with wind only during summer (Table 4).

At a global level (Table 5), the Q. petraea litterfall shows a negative regression with precipitation during winter and spring. Total litterfall also has a negative regression in autumn with wind and a positive regression with spring temperature.
Finally, in Table 2 are the results of the regressions between litterfall of $F$. sylvatica and meteorological variables. Regarding leaves, we observed that the variables that have a direct effect are wind and temperature. Temperature has a negative regression during autumn and winter as the colder it is, the more leaves fall. Wind also has a negative regression during spring, but during winter and summer it has a positive regression. There are also other relationships between variables as delayed effects- if the summer is hot less leaves fall during autumn whereas if the spring is rainy more leaves fall. Another phenomenon can be observed: more litterfall is produced during winter if the autumn is not cold. 
Acorn (Table 3 ) in F. sylvatica only has a direct relationship with temperature, which corresponds to a negative regression, not only in summer there is a significant result, although we noticed the same kind of relationship. We also observed a significant negative regression between the temperature in winter and fruits fall during spring. A second factor to consider is wind, winter wind has positive regressions falling acorn spring and summer, and the summer wind with falling autumn and winter. Twigs and other fractions do not show a clear relationship with meteorological variables.
In terms of total litterfall we found the same pattern as leaves fraction, with a significant relationship in temperature and wind (Table 5).

\section{The Basal Area Increment}

Figure 5, 6 and 7 illustrates the BAI patterns in the three different species during the study period. The main growth period occurs in spring, and there is also a second growth peak which usually occurs in autumn. $Q$. petraea and $Q$. ilex increase their growth every year, while $F$. sylvatica has a sustained growth. The relationship between the meteorological variables and the annual BAI was explored in Table 6.

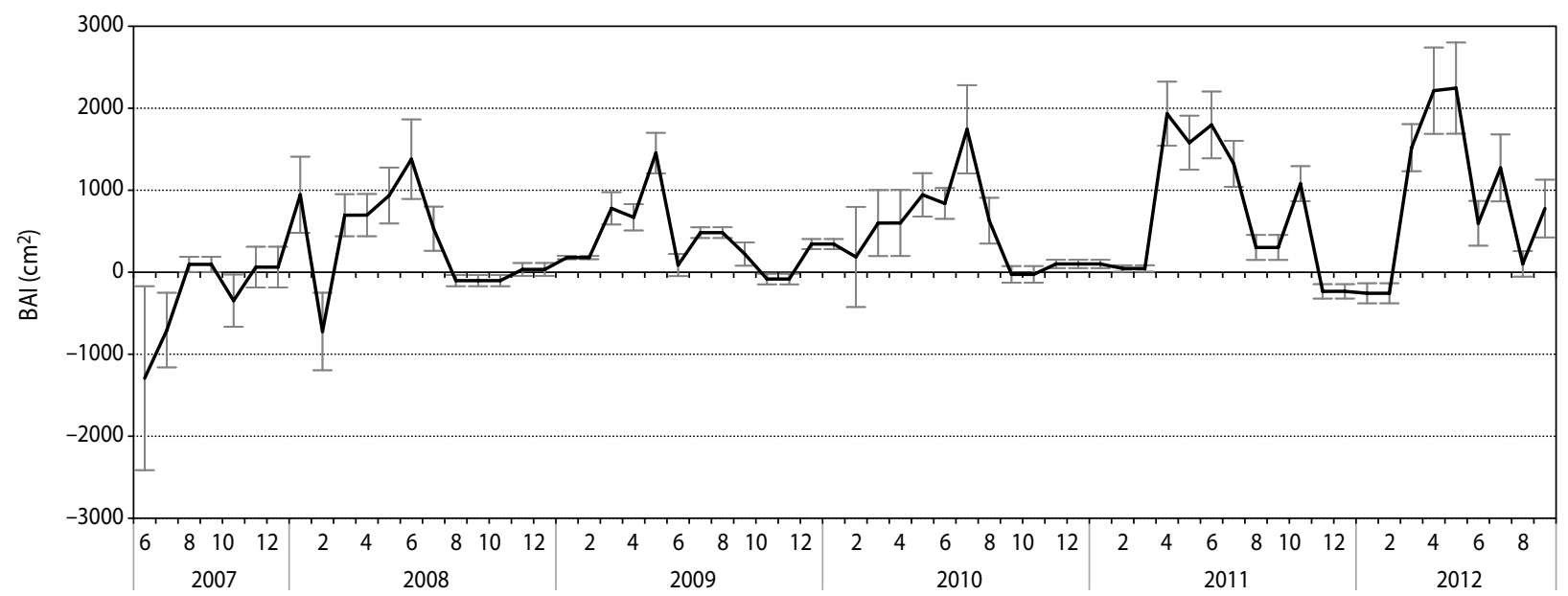

Figure 5. None accumulated monthly growth of Quercus petraea trees, measured as the increment of the basal area, in $\mathrm{cm}^{2}$, using the mean of the three plots of Marmolers. The initial values have a high standard deviation because the band dendrometers need some months to adjust at the tree bark

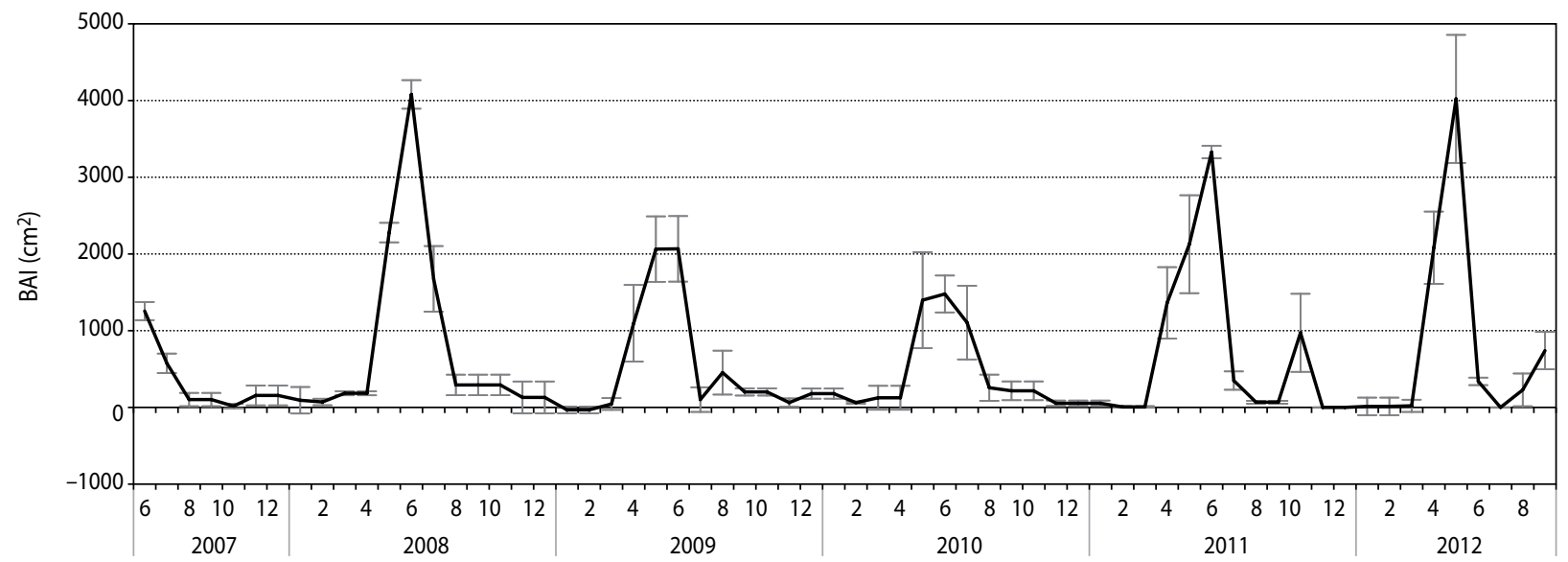

Figure 6. None accumulated monthly growth of Fagus sylvatica trees, measured as the increment of the basal area, in $\mathrm{cm}^{2}$, using the mean of the three plots of Coll de Te 


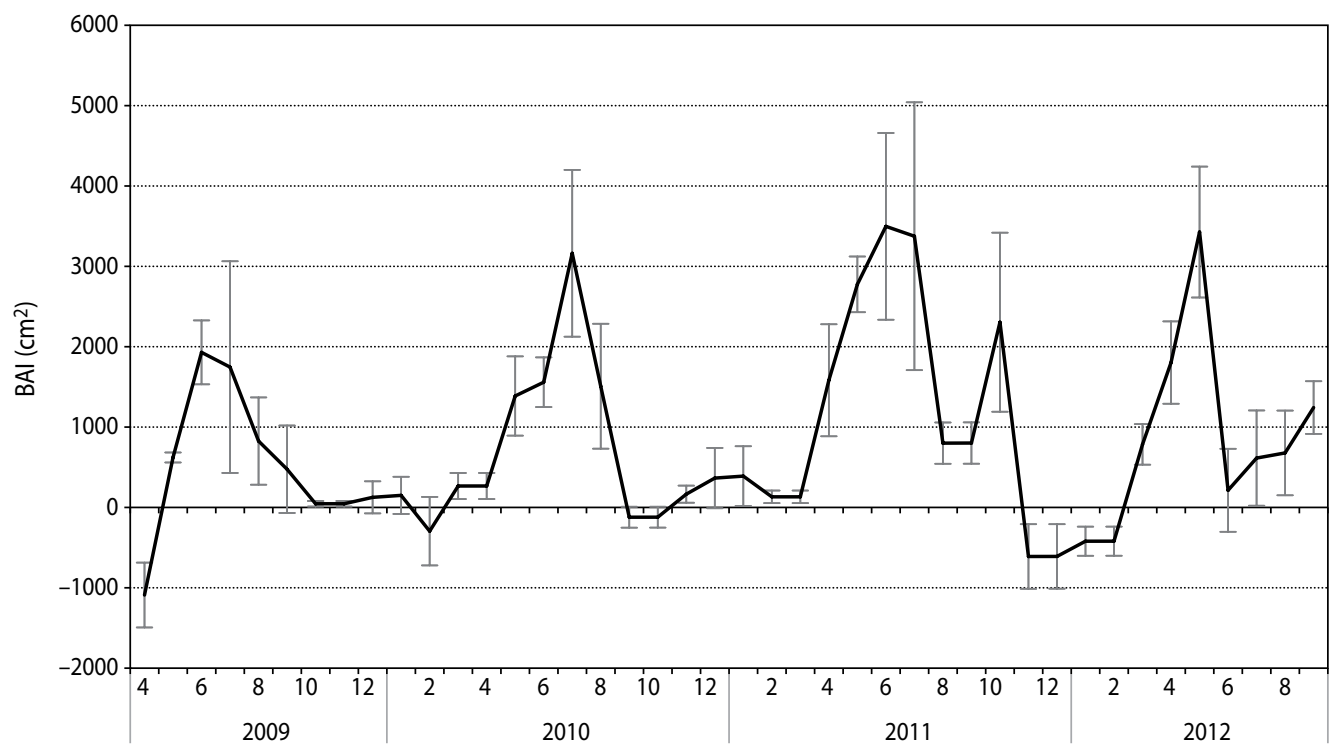

Figure 7. None accumulated monthly growth of Quercus ilex trees, measured as the increment of the basal area, in $\mathrm{cm}^{2}$, using the mean of the three plots of Feixa Llarga. The high standard deviation values indicated the heterogenic arboreal structure of these plots

Table 6. Linear regression between the annual and seasonal meteorological data and the annual BAI (Quercus ilex, Quercus petraea and Fagus sylvatica). The first P-value tests de regression model, the second P-value corresponds to the t-test of the intercept (a) whereas the third P-value corresponds to the t-test of whether the regression coefficient or slope (b) is significantly different from 1. Also there are the coefficient of determination $\left(\mathrm{r}^{2}\right)$ and the residual standard error (SE) of the regression model. The litterfall fractions of this table are the most interesting, the leaves and acorn, and also there are the total litterfall. The table only contents the season that have some kind of significant linear regression. The meteorological data used are: precipitation (P), temperature (T)

\begin{tabular}{|l|c|c|c|c|c|c|c|c|c|}
\hline Species & $\begin{array}{c}\text { Meteorological } \\
\text { variable }\end{array}$ & $\begin{array}{c}\text { Meteorological } \\
\text { variable period }\end{array}$ & $\mathrm{r}^{2}$ & $\mathrm{p}$ & $\mathrm{SE}$ & $\mathrm{a}$ & $\mathrm{p}$ & $\mathrm{b}$ & $\mathrm{p}$ \\
\hline \multirow{4}{*}{$\begin{array}{l}\text { Quercus } \\
\text { ilex }\end{array}$} & $\mathrm{T}$ & Summer & 0,535 & $<0,0500$ & 0,038 & 1,951 & $<0,050$ & $-9,99 \mathrm{E}-02$ & $<0,05$ \\
\cline { 2 - 10 } & $\mathrm{P}$ & Autumn & 0,606 & $<0,0500$ & 0,035 & 0,008 & 0,803 & $3,06 \mathrm{E}-04$ & $<0,05$ \\
\cline { 2 - 10 } & $\mathrm{P}$ & Winter & 0,486 & $<0,0500$ & 0,039 & 0,029 & 0,401 & $2,87 \mathrm{E}-04$ & $<0,05$ \\
\hline $\begin{array}{l}\text { Quercus } \\
\text { petraea }\end{array}$ & $\mathrm{P}$ & Summer & 0,582 & $<0,0500$ & 0,036 & 0,369 & $<0,010$ & $-1,68 \mathrm{E}-03$ & $<0,05$ \\
\hline \multirow{2}{*}{$\begin{array}{l}\text { Fagus } \\
\text { sylvatica }\end{array}$} & $\mathrm{P}$ & Annual & 0,388 & $<0,0500$ & 0,015 & 0,004 & 0,874 & $5,90 \mathrm{E}-05$ & $<0,05$ \\
\cline { 2 - 10 } & $\mathrm{P}$ & Winter & 0,811 & $<0,0001$ & 0,008 & 0,012 & 0,129 & $1,75 \mathrm{E}-04$ & 0,000 \\
\cline { 2 - 10 } & $\mathrm{P}$ & Autumn & 0,442 & $<0,0500$ & 0,017 & 0,041 & $<0,010$ & $1,04 \mathrm{E}-04$ & $<0,05$ \\
\hline
\end{tabular}

The BAI of the evergreen $Q$. ilex shows a negative regression with the summer temperature. It also shows a positive regression in autumn and winter with precipitation and a negative regression in summer. A different pattern was observed in Q. petraea BAI, which only shows relationships with precipitation. This tree shows two positive regressions, the first one with annual precipitation and the second one with winter precipitation. Finally, in F. sylvatica it shows relations with precipitation and temperature. The autumn rainfalls have a positive regression, and the same occurs with winter temperature and the only negative regression that they have is with summer temperature. 


\section{Discussion}

\section{Composition and phenology of the litterfall}

The mean litterfall calculated for the three forests in Montseny (4.93 Mg$\cdot \mathrm{ha}^{-1} \cdot$ year $\left.^{-1}\right)$ gives similar values to other temperate forests in the world $\left(4.7-6 \mathrm{Mg} \mathrm{ha}^{-1} \cdot\right.$ year $\left.^{-1}\right)$ (Zhang et al. 2014). In the case of F. sylvatica we obtained higher values than by Quercus, but as we will see, these results are quite common.

Different studies show that annual litterfall production in Q. ilex is between $3.8-6.94 \mathrm{Mg} \cdot \mathrm{ha}^{-1} \cdot$ year $^{-1}$ (Verdu et al. 1980; Cole and Rapp 1981; Ferrés and Llanza 1984; Rodà et al. 1999; Bussotti et al. 2003; Andivia et al. 2009), values which are similar to those found in this study. The present study gives close results to La Castanya (Verdu et al. 1980), with a production of $4.5 \mathrm{Mg} \mathrm{ha}^{-1}$. year-1. It is a holm oak forest in similar conditions, in the same massif. In other evergreen Quercus, the results are also similar. In Quercus rotundifolia $4.7 \mathrm{Mg} \cdot \mathrm{ha}^{-1} \cdot \mathrm{year}^{-1}$ (Sá et al. 2005) and Quercus suber 3.9-5.1 Mg.ha' $\mathrm{hear}^{-1}$ (Oliva et al. 1992; Sá et al. 2005; Caritat et al. 2006). Specifically for $Q$. suber in Sant Hilari, a close area to the Montseny massif, a production of $4.6 \mathrm{Mg} \cdot \mathrm{ha}^{-1} \cdot \mathrm{year}^{-1}$ has been found which is very similar to the one registered in this study for $Q$. ilex. However, in warmer areas a lower production was obtained (Oliva et al. 1992). This is due to the fact that, in general, the Mediterranean trees are very sensitive to the impacts of variability of meteorological conditions (Bussotti et al. 1995), but in the Montseny they are attenuated due to very favourable conditions.

The annual production of litterfall of $Q$. petraea found in different European studies is 2.85-4.1 Mg.ha ${ }^{-1} \cdot$ year $^{-1}$ (Carlisle et al. 1966; Carceller et al. 1989; Kotroczó et al. 2012; Novák et al. 2014), values which are slightly below the ones obtained in this study. The differences are probably due to the fact that the forest of Marmolers tends to maturity and has a relatively high density of large trees. The closest value is one of 4.1 Mg ha $^{-1} \cdot$ year $^{-1}$ of Czech Republic (Novák et al. 2014) but it is a younger forest, so there could be a lower production of litterfall. In the case of $Q$. petraea in Montseny, the litterfall values are more similar to the ones obtained for other deciduous tree such as Quercus robur with values usually between $3.33-7 \mathrm{Mg} \cdot \mathrm{ha}^{-1} \cdot$ year $^{-1}$ (Diaz-Maroto and Vila-Lameiro 2006; Hansen et al. 2009).

High values of litter production are found for $F$. sylvatica in Coll de $\mathrm{Te}$ in relation to the other two forests.
The differences are probably because the beech is composed of bigger trees than the others. Regarding other $F$. sylvatica forests, the annual production of litterfall is about 2.1-5.8 Mg.ha-1.year ${ }^{-1}$ (Santa Regina 1987; Lebret et al. 2001; Novák and Slodicak 2008; Hansen et al. 2009). In our case we found a higher amount, probably due to the maturity of the beech in Montseny. In a study where two beech forests of different ages are compared Novak and Slodicak (2008) found a similar value to the one in Montseny with a production of $5.8 \mathrm{Mg} \cdot \mathrm{ha}^{-1} \cdot \mathrm{year}^{-1}$, and where they could conclude that the oldest forest was the most productive (Novák and Slodicak 2008).

With respect to the fractions of the litterfall in the three species, the greatest fraction is composed of leaves, as it has been proved in other studies (Santa Regina 1987; Carceller et al. 1989; Martín et al. 1996; Rapp et al. 1999). Especially in our deciduous forests, the leaves fraction is high, around $70 \%$, and this could be due to a greater degree of maturity. A similar value has been observed in several studies of beech (Rapp et al. 1999; Lebret et al. 2001) although in studies with older forest the leaf fraction tends to represent about 50\% of the total litterfall (Kira and Shidei 1967).

In addition, F. sylvatica and Q. petraea (Figure 3) had a seasonal pattern in their monthly foliar litterfall, which is consistent with the typical pattern of leaf fall in deciduous species (Witkamp and Van der Drift 1961; Verdu 1984) in cold and temperate regions in the northern hemisphere, where peak leaf fall occurs in autumn. However, the species differ in the month of maximum leaf fall, which normally occurs in November in the $Q$. petraea forests but varies in F. sylvatica forests according to the year. This is due to the fact that the beech is more sensitive to climatic conditions. In the $Q$. ilex forest, however, there are two peaks in the intra-year litterfall (Figure 4). The first one takes place in spring, after the sprouting, and it is common in Mediterranean species (Caritat et al. 1996; Martín et al. 1996; Rapp et al. 1999; Bussotti et al. 2003). The second peak in the intra-year litterfall occurs, as various authors have observed, in other Mediterranean forests (Leonardi et al. 1992; Bussotti et al. 2003; Caritat et al. 2006). A second leaf fall may occur in October and November.

Fruits fall present different proportions among the species. Q. ilex forest accounts for $15.89 \%$ of the total litterfall, higher than the $6.3 \%$ found by Bellot et al. (1992) in the Prades (NE Spain), probably because of 
the more northern situation of the Montseny Massif and its more humid and stable climate than Prades. Nevertheless, apart from the influence of weather conditions, we should also take into account the great inter-annual variability in fruit production in the studied species, since years of abundance are often followed by years of low production. In 2008 a $Q$. petraea vintage has been observed, when the acorn raised to $12.76 \%$, while during the rest of the year the average was of $3.9 \%$. In $F$. sylvatica vintage is not so clear although there are two peaks in 2007 and another one in 2010, around $20 \%$. In order to deepen this fraction it would be necessary to have an even longer series, as this would actually allow us to calculate how often vintages take place and how the cycle of fruit production occurs.

Twigs represent a smaller fraction than leaves and acorn, but there are differences between species. In Quercus forest twigs are about $13 \%$ of the litterfall, while in F. sylvatica it is $11 \%$. This has also been observed in other studies (Hansen et al. 2009).

\section{Influence of meteorological variables on leaves fall}

Q. ilex falling of leaves has many significant relationships with temperature. In summer high temperatures make photosynthesis difficult, but we can see that they are not high enough to cause an increase in the leaves fall. Furthermore, the loss of $Q$. ilex leaves would be very expensive, because the cost of producing evergreen leaves is higher than that of deciduous leaves due to the greater concentration of lignin (Aerts 1995). Thus, the higher production cost of evergreen leaves ensures that they are preserved for longer than in deciduous trees. During autumn in $Q$. ilex we have seen that precipitation generates an increase in the leaves production renewing the crown because the tree takes advantage of favourable conditions (i.e. rainfall in September and October) (Bellot et al. 1992). This increase in the renewal has effects not only in autumn, but also in winter, as the renewed crown in autumn reduces the falling leaves in winter.

Q. petraea leaves fall has a maximum peak in autumn and a minimum in winter and may be modified by two factors - temperature and wind. The strong winds of summer and autumn make a lot of leaves fall, and for this reason less leaves fall in the following season. During very hot years less leaves fall during autumn, as they must have fallen in summer or even spring. In fact, in other deciduous species it seems that temperature does reduce the amount of spring leaves biomass (Novák and Slodicak 2008).

$F$. sylvatica leaves fall occurs in autumn and at the beginning of winter, when temperatures drop but if this reduction is not important enough in autumn, the leaves drop moves towards winter. An important factor during periods when most leaves do not fall is wind, making leaves fall during windy days. In $F$. sylvatica we observed that if the summer has been hot, less leaves fall during autumn. This is probably due to the fact that during summer there is a little increase in the leaves fall, but for the moment this rise does not have a significant relationship with summer temperature.

It has been observed that the leaves fall in deciduous is mainly regulated by temperature and wind, a mechanical factor. Temperature acts in two ways, the most obvious being with the arrival of cold in autumn when leaf fall is activated. On the other hand, high temperatures in spring and summer seem to make less leaves fall during autumn. We believe that this is because during the previous months, trees have been losing part of the leaves due to the heat. However, in this study no significant results were obtained from the summer temperature and summer leaves fall. Therefore, it is necessary to continue this study, as a longer series allows us to see relationships of this kind, although they are beginning to sense they are not entirely clear.

In deciduous trees of the Montseny massif we did not detect precipitation as a limiting factor in the production of leaves, which makes that for the photosynthesis the trees always have similar foliage. So temperature that regulates the falling leaves acquires a prominent role as a regulator of the primary production of the tree. However, a premature fall of the leaves during summer could reduce it; while at the same time it should be taken into account that a slightly cold autumn could delay the loss of leaves. Considering that in Montseny the temperature has risen between $1.2-1.4^{\circ} \mathrm{C}$ during the last 50 years (Peñuelas and Boada 2003), it is important to consider the possible effects that this can have on primary production.

Wind factor becomes secondary for $Q$. ilex and the renewal of leaves is related to water availability, and it is during spring and autumn when leaves fall. As compared to the summer heat, we can see there is a different 
relationship with falling leaves in relation to deciduous, because in this case the heat does not make more leaves fall, but the opposite. We believe that while in deciduous litterfall is slightly increased by the heat of summer, for $Q$. ilex the summer heat does not make more leaves fall, because this species can bear temperatures without increasing drop of leaves. We could say that $Q$. ilex withstands the summer, stopping the leaves renewal, while deciduous trees seem to lose some leaves out of season.

\section{Influence of meteorological variables on fruits fall}

Acorns fall of $Q$. ilex is favoured by the mechanical effect of rains, while an increase in rainfall may also favour the final growth of the seeds. Moreover, it can be observed that a cold autumn makes some of its acorns delayed until winter.

Q. petraea acorns usually fall in autumn, but some years have a maximum drop in summer, which corresponds to rainy and cold springs (specifically in 2008 when there was a high fall of acorn, which was preceded by the second rainiest spring of the study).

The fruit fall of $F$. syvlatica is mainly marked by low temperatures. There is also the wind effect, which weakens the grip of fruits and then makes them fall.

The factors involved in the fall of fruit depend on the species but they all have more or less their maximum peak in autumn. We must also highlight that because of the fall fruits have vintages. This parameter should continue to be studied for longer in order to be able to analyse the factors that determine the occurrence of vintage.

\section{Influence of meteorological variables on BAI}

The growth of the trees is similar to other Mediterranean forests, restricted to spring and part of autumn, when rainfall is most abundant and temperatures are moderate (Montserrat-Martí et al. 2009; Gutiérrez et al. 2011). In our study we usually found a second growth peak in autumn, less important and shorter than in spring and related to favourable weather conditions (i.e. heavy rainfall and no freezing temperatures) (Figure 5, 6 and 7).

The annual BAI of $Q$. petraea (Figure 5) found in Marmolers is $5.8 \mathrm{~cm}^{2}$ year-1 less than the growth of other studies from Europe (Lebourgeois et al. 2005; VilaLameiro and Diaz-Maroto 2008). This fact shows that this forest is placed in the south limit of its distribution. In addition, the BAI of $F$. sylvatica $\left(7.4 \mathrm{~cm}^{2} \cdot\right.$ year $\left.^{-1}\right)$ is lower than in other studies from Montseny (Jump et al. 2006; Peñuelas et al. 2008). The BAI of $Q$. ilex $\left(11.8 \mathrm{~cm}^{2} \cdot\right.$ year $\left.^{-1}\right)$ was the highest of the three studied trees, and higher than other $Q$. ilex forest from central Spain (Granda et al. 2013). This is because of the humid conditions in Montseny and the selective logging done in 2007.

The annual BAI of the three species was correlated with the meteorological variables. In evergreen tree $Q$. ilex rainy autumns play an important role in the second peak of growth. However, hot summers reduce BAI, as it has been shown in other studies (Corcuera et al. 2004; Gea-Izquierdo et al. 2011; Gutiérrez et al. 2011; Granda et al. 2013). In our study the effect is probably clearer because after the logging, when the forest density was reduced, it made the remaining trees more sensitive to the summer impacts.

Instead, the deciduous $Q$. petraea only has correlation with annual and winter precipitation. In other studies with other Mediterranean deciduous oaks (Granda et al. 2013), there is the same relationship between growth and precipitation (February), and also in this study they found a positive relation with spring (April-May) rainfalls. However, it does not have any correlation with summer precipitation and temperatures, which would indicate that the $Q$. petraea can withstand the actual climatic conditions of the Montseny massif, without extremely hot and dry summers. The other deciduous tree, $F$. sylvatica, shows an increment in the annual growth in the years with pouring autumns when the second peak of growth is higher. This tree shows that hot summers produce a decline in the annual growth, like in other studies (Gutiérrez 1988; Jump et al. 2006; Tegel et al. 2014; Rozas et al. 2015).

The BAI variation between years shows a rise in growth in both Quercus, but not in F. sylvatica. Other studies even found a decline of the growth of $F$. sylvatica (Jump et al. 2006). Taking into consideration that Mediterranean trees such as Q. ilex do not stop their growth, probably in the future they could replace the F. sylvatica forest in the Montseny (Peñuelas and Boada 2003). Nevertheless, in the Montseny massif we have to take into consideration the presence of $Q$. petraea, a deciduous tree that does not decline its growth like $F$. sylvatica, on the contrary, the BAI increases. This higher tolerance of $Q$. petraea to the climate change leads us to believe that it could also replace $F$. sylvatica in some 
zones of the Montseny massif. This vulnerability of $F$. sylvatica, before $Q$. petraea has also been found in central Europe (Zimmermann et al. 2015).

\section{Conclusions}

Having three different forest species, one evergreen forest and two deciduous forests, in the same location is useful to study the relation of litterfall and BAI before meteorological variability. The litterfall shows interesting patterns in autumn when the leaves of deciduous trees fall. In this investigation we observed the autumn decline of leaves fall when the summer is warmer, because they have fallen in summer. Although nowadays we haven't found a significant direct effect on warm summer and leaves fall in this season, this pattern will probably be clearer in a longer study. Instead, the evergreen $Q$. ilex hot summers do not have this effect. Thus, in the future if there are more warm summers, we expect a decline in the primary annual production of the deciduous trees.

Concerning growth, we found that $F$. sylvatica does not increase the BAI during the study period. In fact hot summers produce a decline in the annual growth. Instead, in $Q$. petraea the BAI increases in a very clear way and summer temperature does not have a significant effect. Thus, F. sylvatica is more vulnerable to the increase in summer temperature than $Q$. petraea. Considering that in the past 50 years temperatures have increased in the Montseny massif (Peñuelas and Boada 2003), it is expected that the future climate change will have impacts on the forest systems. The decline in population of $F$. sylvatica is expected, while $Q$. ilex and $Q$. petraea will bear the new conditions better.

\section{References}

Aerts R. 1995. The advantages of being evergreen. Trends in Ecology and Evolution, 10, 402-407.

Andivia E., Alejano R., Vázquez J. 2009. Evolución mensual del desfronde en dos dehesas de Quercus ilex subs. ballota de la provincia de Huelva. Influencia de la poda. 5o Congr. For. Español.

Andivia E., Vázquez-Piqué J., Fernández M., Alejano R. 2013. Litter production in Holm oak trees subjected to different pruning intensities in Mediterranean dehesas. Agroforestry Systems, 87 (3), 657-666. doi: 10.1007/s10457-012-9586-5.

Aranda I., Gil L., Pardos J.A. 2000. Water relations and gas exchange in Fagus sylvatica L. and Quercus petraea (Mattuschka) Liebl. in a mixed stand at their southern limit of distribution in Europe. Trees, 14, 344-352. doi: 10.1007/s004680050229.

Bellot J., Sánchez J.R., Lledó M.J., Martinez P., Escarré A. 1992. Litterfall as a measure of primary production in Mediterranean holm-oak forest. Vegetatio, 99 (1), 69-76. doi: 10.1007/BF00118211.

Bolòs O. 1983. La vegetació del Montseny. Diputació de Barcelona, Barcelona.

Bugmann H. 1997. Sensitivity of forests in the European Alps to future climatic change. Climate Research, 8 (1), 35-44. doi: 10.3354/cr008035

Bussotti F., Borghini F., Celesti C., Leonzio C., Cozzi A., Bettini D., Ferretti M. 2003 Leaf shedding, crown condition and element return in two mixed holm oak forests in Tuscany, central Italy. Forest Ecology and Management, 176, 273-285.

Bussotti F., Ferretti M., Cozzi A., Grossoni P., Bottacci A., Tani C. 1995. Crown status of holm oak (Quercus ilex L.) trees as related to phenology and environmental stress. Water, Air, and Soil Pollution, 85 (3), 1269-1274. doi: 10.1007/BF00477156

Carceller F., Santa Cecilia M., Vallejo V., Novo M. 1989. Introduccion al ciclo de la materia organica en cinco ecosistemas forestales del Moncayo. Turiaso, 9, 361-372.

Caritat A., Bertoni G., Molinas M., Oliva M., Domínguez-Planella A. 1996. Litterfall and mineral return in two cork-oak forests in northeast Spain. Annals of Forest Science, 53 (6), 1049-1058.

Caritat A., García-Berthou E., Lapeña R., Vilar L. 2006. Litter production in a Quercus suber forest of Montseny (NE Spain) and its relationship to meteorological conditions. Annals of Forest Science, 63 (7), 791-800.

Carlisle A., White A.H.F., Brown E.J. 1966. Litter fall, leaf production and the effects of defoliation by Tortrix viridana in a Sessile Oak (Quercus petraea) woodland. Journal of Ecology, 54, 65-85.

Cole D.W., Rapp M. 1981. Elemental cycling in forest ecosystems. In: Dynamic properties of forest eco- 
systems (ed.: D.E. Reichle), Cambridge University Press, Cambridge, 341-410.

Corcuera L., Camarero J.J., Gil-Pelegrín E. 2004. Effects of a severe drought on Quercus ilex growth and xylem anatomy. Trees: Structure and Function, $18,83-92$.

Diaz-Maroto I.J., Vila-Lameiro P. 2006. Litter production and composition in natural stands of Quercus robur L. (Galicia, Spain). Polish Journal of Ecology, 54 (3), 429-439.

Ferrés L., Roda F., Verdu A.M.C., Terradas J. 1984. Circulación de nutrientes en algunos ecosistemas forestales del Montseny (Barcelona). Mediterránea. Serie de Estudios Biológicos, 7, 139-166.

Fotelli M.N., Nahm M., Radoglou K., Rennenberg H., Halyvopoulos G., Matzarakis A. 2009. Seasonal and interannual ecophysiological responses of beech (Fagus sylvatica) at its south-eastern distribution limit in Europe. Forest Ecology and Management, 257:1157-1164. doi: 10.1016/j.foreco.2008.11.026

Gea-Izquierdo G., Cherubini P., Cañellas I. 2011. Treerings reflect the impact of climate change on Quercus ilex $\mathrm{L}$. along a temperature gradient in Spain over the last 100 years. Forest Ecology and Management, 262, 1807-1816. doi: 10.1016/j.foreco.2011.07.025

Granda E., Camarero J.J., Gimeno T.E., MartínezFernández J., Valladares F. 2013. Intensity and timing of warming and drought differentially affect growth patterns of co-occurring Mediterranean tree species. European Journal of Forest Research, 132, 469-480. doi: 10.1007/s10342-013-0687-0.

Gutiérrez E. 1988. Dendroecological study of Fagus sylvatica L. in the Montseny Mountains (Spain). Acta Oecologica, 9 (3), 301-309.

Gutiérrez E., Campelo F., Camarero J.J., RibasM., Muntán E., Nabais C., Freitas H. 2011. Climate controls act at different scales on the seasonal pattern of Quercus ilex L. stem radial increments in NE Spain. Trees: Structure and Function, 25 (4), 637-646. doi: 10.1007/s00468-011-0540-3.

Hansen K., Vesterdal L., Schmidt I.K., Gundersen P., Sevel L., Bastrup-Birk A., Pedersen L.B., BilleHansen J. 2009. Litterfall and nutrient return in five tree species in a common garden experiment. Forest Ecology and Management, 257 (10), 2133-2144. doi: 10.1016/j.foreco.2009.02.021.
Jacoby G.C., D'Arrigo R.D. 1997. Tree rings, carbon dioxide, and climatic change. PNAS, 94, 8350-8353.

Jump A.S., Hunt J.M., Peñuelas J. 2006. Rapid climate change-related growth decline at the southern range edge of Fagus sylvatica. Global Change Biology, 12, 2163-2174. doi: 10.1111/j.1365-2486.2006.01250.x

Kira T., Shidei T. 1967. Primary production and turnover of organic matter in different forest ecosystems of the Western Pacific. Japanese Journal of Ecology, 17, 70-87.

Kotroczó Z., Veres Z., Fekete I., Papp M., Tóth J.A. 2012. Effects of climate change on litter production in a Quercetum petraeae-cerris forest in Hungary. Acta Silvatica et Lignaria Hungarica, 8, 31-38. doi: 10.2478/v10303-012-0003-6.

Lebourgeois F., Bréda N., Ulrich E., Granier A. 2005. Climate-tree-growth relationships of European beech (Fagus sylvatica L.) in the French Permanent Plot Network (RENECOFOR). Trees: Structure and Function, 19, 385-401. doi: 10.1007/s00468004-0397-9.

Lebret M., Nys C., Forgeard F. 2001. Litter production in an Atlantic beech (Fagus sylvatica L.) time sequence. Annals of Forest Science, 58, 755-768.

Leonardi S., Rapp M., Failla M., Komaromy E. 1992. Biomasse, minéralomasse, productivité et gestion de cer-tains éléments biogènes dans une forêt de Quercus suber L. en Sicile (Italie). Ecologia Mediterranea, 89-98.

Liu C., Westman C.J., Berg B., Kutsch W., Wang G.Z., Man R., Ilvesniemi H. 2004. Variation in litterfall-climate relationships between coniferous and broadleaf forests in Eurasia. Global Ecology and Biogeography, 13, 105-114. doi: 10.1111/j.1466882X.2004.00072.x.

Martín A., Gallardo J., Regina I.S. 1996. Aboveground litter production and bioelement potential return in an evergreen oak (Quercus rotundifolia) woodland near Salamanca (Spain). Annales des Sciences Forestieres, 53 (4), 811-818.

Mátyás C. 2010. Forecasts needed for retreating forests. Nature, 464, 9401.

Montserrat-Martí G., Camarero J.J., Palacio S., PérezRontome C., Milla R., Albuixech J., Maestro M. 2009. Summer-drought constrains the phenology and growth of two coexisting Mediterranean oaks with contrasting leaf habit: Implications for their 
persistence and reproduction. Trees: Structure and Function, 23, 787-799. doi: 10.1007/s00468-0090320-5.

Novák J., Dušek D., Slodičák M. 2014. Quantity and quality of litterfall in young oak stands. Journal of Forest Science, 60 (6), 219-225.

Novák J., Slodicak M. 2008. Quantity and quality of litter-fall in young European beech (Fagus silvatica L.) stands in localities naturally dominated by broadleaves. Austrian Journal of Forest Science, 125 (1), 67-78.

Oliva M., Molinas M., Caritat A. 1992. Variacion estacional del desfronde en dos parcelas de alcornocal. Scientia Gerundensis, 18, 121-130.

Peñuelas J., Boada M. 2003. A global change-induced biome shift in the Montseny mountains (NE Spain). Global Change Biology, 9 (2), 131-140.

Peñuelas J., Hunt J.M., Ogaya R., Jump A.S. 2008. Twentieth century changes of tree-ring $\delta 13 \mathrm{C}$ at the southern range-edge of Fagus sylvatica: Increasing water-use efficiency does not avoid the growth decline induced by warming at low altitudes. Global Change Biology, 14, 1076-1088. doi: 10.1111/j.13652486.2008.01563.x.

Rapp M., Santa Regina I., Rico M., Gallego H.A. 1999. Biomass, nutrient content, litterfall and nutrient return to the soil in Mediterranean oak forests. Forest Ecology and Management, 119, 39-49.

Rodà F., Retana J., Gracia C.A., Bellot J. 1999. Ecology of mediterranean evergreen oak forests. Ecological Studies. Analysis and Synthesis, 137, 1-20. doi: 10.1007/978-3-642-58618-7.

Rozas V., Camarero J.J., Sangüesa-Barreda G., Souto G., García-González I. 2015. Summer drought and ENSO-related cloudiness distinctly drive $\mathrm{Fa}$ gus sylvatica growth near the species rear-edge in northern Spain. Agricultural and Forest Meteorology, 201, 153-164.

Sá C., Madeira M., Gazarini L. 2005. Produção e decomposição de folhas da folhada de Quercus suber L. e Q. rotundifolia Lam. Rev. Cienc. Agrar., 28 (2), 257-272.

Santa Regina I. 1987. Contribución al estudio de la dinámica de la materia orgánica y bioelementos en bosques en la Sierra de Béjar. Universidad de Salamanca.

Tegel W., Seim A., Hakelberg D., Hoffmann S., Panev M., Westphal T., Büntgen U. 2014. A recent growth increase of European beech (Fagus sylvatica $\mathrm{L}$.) at its Mediterranean distribution limit contradicts drought stress. European Journal of Forest Research, 133 (1), 61-71. doi: 10.1007/ s10342-013-0737-7.

Vayreda J., Martínez-Vilalta J., Banqué M. 2013a. Els boscos davant del canvi climàtic. In: CREAF, Oficina Catalana del Canvi Climàtic, Generalitat de Catalunya. CREAF, Barcelona.

Vayreda J., Martínez-Vilalta J., Banqué M. 2013b. Decaïment dels Boscos a Catalunya: DEBOSCAT.

Verdu A.M.C. 1984. Circulació de nutrients en ecosistemes forestals del Montseny: caiguda de virosta i descomposició de les fulles. Universitat Autònoma de Barcelona.

Verdu A.M.C., Ferrés L., Roda F., Terradas J. 1980. Estructuta y funcionalismo de un encinar montano en el Montseny. Mediterranéa, 4, 51-67.

Vila-Lameiro P., Diaz-Maroto I.J. 2008. Las masas actuales de Quercus petraea en Galicia. Forest Systems, 11, 5-28.

Weber P., Bugmann H., Fonti P., Rigling A. 2008. Using a retrospective dynamic competition index to reconstruct forest succession. Forest Ecology and Management, 254, 96-106. doi: 10.1016/j.foreco.2007.07.031

Witkamp M., Van der Drift J. 1961. Breakdown of forest litter in relation to environmental factors. Plant and Soil, 15, 295-311.

Zhang H., Yuan W., Dong W., Liu S. 2014. Seasonal patterns of litterfall in forest ecosystem worldwide. Ecological Complexity, 20, 240-247. doi: 10.1016/j. ecocom.2014.01.003.

Zimmermann J., Hauck M., Dulamsuren C., Leuschner C. 2015. Climate warming-related growth decline affects Fagus sylvatica, but not other broadleaved tree species in Central European mixed forests. Ecosystems, 18 (4), 560-572. doi: 10.1007/ s10021-015-9849-x. 